\title{
New Insights Into the Regulation of TGF- $\beta /$ Smad and MPK Signaling Pathway Gene Expression by Nasal Allergen and Methacholine Challenge Test in Asthma.
}

Michał Panek ( $\square$ michalmp@poczta.onet.pl)

Medical University of Lodz https://orcid.org/0000-0002-3718-4793

Michał Seweryn Karbownik

Medical University of Lodz: Uniwersytet Medyczny w Lodzi

Karol Maksymilian Górski

Medical University of Lodz: Uniwersytet Medyczny w Lodzi

Marcelina Koćwin

Medical University of Lodz: Uniwersytet Medyczny w Lodzi

Grzegorz Kardas

Medical University of Lodz: Uniwersytet Medyczny w Lodzi

Mateusz Marynowski

Medical University of Lodz: Uniwersytet Medyczny w Lodzi

\section{Piotr Kuna}

Medical University of Lodz: Uniwersytet Medyczny w Lodzi

\section{Research}

Keywords: asthma, inflammation, TGF, Smad, MAPK, gene expression

Posted Date: August 18th, 2021

DOI: https://doi.org/10.21203/rs.3.rs-796994/v1

License: (c) (i) This work is licensed under a Creative Commons Attribution 4.0 International License. Read Full License 


\section{Abstract}

Background

Asthma is a heterogeneous chronic inflammatory disease of the bronchi, the course of which is significantly influenced by specific and non-specific extrinsic factors. The aim of this study was to evaluate the effect of these factors on changes in the mRNA expression of genes encoding the TGF- $\beta$ (TGF- $\beta 1$ and TGF- $\beta 3$ ) - Smad (MPK1/3, Smad1/3/6/7) signaling pathway in asthmatic patients.

Methods and Results

Seventy-five subjects were included in the study, of whom 27 (nine men and 18 women) received an intranasal allergen provocation (specific factors) and 48 (17 men and 31 women) were administered a methacholine provocation (non-specific factors).

Conclusion

Both examined types of challenges were found to contribute to changes in the relative expression of genes of the TGF- $\beta$ (TGF- $\beta 1$ and TGF- $\beta 3$ ) - Smad (MPK1/3, Smad1/3/6/7) signaling pathway in asthmatic patients. A decrease was noted for the MAPK1, MAPK3, Smad3, Smad6 and Smad7 genes, while an increase of up to 2.5 times was observed for the TGF- $\beta 1$ gene. Our findings suggest that intranasal allergen or bronchial methacholine challenge influences the mRNA expression of the TGF- $\beta 1-$ MPK1/3 and Smad3/6/7 genes.

\section{Introduction}

Asthma is a heterogeneous chronic inflammatory disease of the bronchi, the course of which is significantly influenced by extrinsic factors, both specific ones, such as allergens, and non-specific ones, such as pollutants and other analogous/related substances $[1,2,3]$. However, irrespective of inducer type, the course of asthma is characterized by bronchial remodeling as a result of TGF- $\beta$ overexpression $[4,5,6]$. TGF- $\beta$ is a profibrotic cytokine that stimulates the growth and differentiation of many cell types, controls their proliferation and apoptosis, and stimulates fibroblasts and bronchial smooth muscle cells to modulate the metabolism of extracellular matrix (ECM) proteins. In humans, it is found in three isoforms: TGF $\beta-1$, TGF $\beta-2$ and TGF $\beta-3$. TGF- $\beta$ production is also associated with the presence of eosinophils in the airways of asthmatic patients. The TGF- $\beta$ superfamily is a group of key mediators that play a role in the regulation of allergic and non-allergic inflammation, and has a significant impact on airway remodeling in asthma $[7,8,9]$.

TGF- $\beta$ signaling acts via various intracellular effectors, one of which is the Smad protein group. The Smad proteins are activated by TGF- $\beta$ receptors and travel to the cell nucleus, where they regulate the transcription of over 500 genes, including those responsible for bronchial remodeling [10-17].

TGF- $\beta$ activates the TGF $\beta$ RI/TGF $\beta R$ II receptor (ALK5), thus inducing intracellular stimulation of MAPK (MitogenActivated Protein Kinase 1 and 3), TAK1 (Transforming growth factor beta-Activated Kinase 1), JNK (c-Jun Nterminal kinase), ERK (Extracellular signal-Regulated Kinase) and p38 synthesis without Smad protein involvement. The TGFBRI/TGFßRII receptor (ALK1) activates Smad1 in the Smad1/5 complex; in addition, in cooperation with Smad4 protein, it also activates the intranuclear Smad1/4/5 complex and various transcription factors (TFs). 
In turn, the Smad6 and Smad7 proteins, which inhibit the TGF- $\beta$-Smad intracellular signaling pathway, attenuate the activation of TGFBRI / TGF $\beta$ RII (ALK5) and TGF $\beta$ RI / TGF $\beta R I I$ (ALK1) receptors; however, the activation of these receptors varies between specific factors and non-specific factors. Hence, the cellular response of the TGF- $\beta$ / Smad and MPK signal pathway proteins to nasal allergen challenge (specific factors) and methacholine challenge (non-specific factors) plays a key role in the pathogenesis of asthma, and bronchial remodeling $[5,10$, $14,15,16,18,19]$.

In vitro and in vivo studies indicate that specific and non-specific provoking agents can induce bronchial remodeling independent of inflammation: active provocation with allergen causes bronchospasm and eosinophilic inflammation, while provocation with methacholine causes bronchospasm but without eosinophilic inflammation $[5,10,14,15,16,18,19]$. Hence, such testing can be used to show the effect of specific and nonspecific factors on the molecular level in patients with asthma.

\section{Aim}

The aim of this study was to evaluate the effect of nasal allergen challenge and methacholine challenge on the mRNA expression of genes encoding the TGF- $\beta$ (TGF- $\beta 1$ and TGF- $\beta 3$ ) - Smad (MPK1/3, Smad1/3/6/7) signaling pathway in peripheral blood mononuclear cells (PBMC) from asthma patients.

\section{Availability of data and materials}

\section{Ethical Approval and Consent to participate}

The study was approved by the local Ethics Committee (consent of the Research Review Board of the Medical University of Lodz, Lodz, Poland; no. RNN/133/09/KE). All participation was voluntary, and all participants provided their written informed consent to take part prior to enrolment.

Study group

A convenience sample of inpatients and outpatients with asthma (diagnosed according to the ICD-10 classification, code J45) was recruited in 2019-2020 from the Department of Internal Medicine, Asthma and Allergy, the Department of Pneumonology and Allergology, the Department of General and Oncological Pulmonology and the Specialist Outpatient Clinic of Pulmonary Diseases and Allergology; all of which were parts of N. Barlicki memorial University Clinical Hospital No. 1 of the Medical University of Lodz. Medical data for the survey questionnaire (medical questionnaire) were collected by specialists in Internal Medicine, Allergology and lung diseases.

All participants had been qualified to the study by specialists (given above). Following enrolment, all underwent intranasal allergen provocations or methacholine tests according to medical recommendations and in compliance with current standards for such tests. In addition, $9 \mathrm{~mL}$ blood samples were collected at three time points: once before provocation (at the time coded $0 \mathrm{~h}$ ), and then at one and 24 hours after provocation. Peripheral venous blood was collected from the ulnar vein. The patients were divided into two separate cohorts: one received a nasal allergen challenge, and the other received methacholine challenge.

Asthma diagnosis 
Asthma diagnosis was established according to GINA 2019 (The Global Initiative For Asthma) recommendations, based on clinical asthma symptoms and a lung function test. The level of asthma severity and control was determined on the basis of GINA Report Guidelines. All the participants underwent subjective examinations based on interview. Demographic and lifestyle data was then taken, e.g. gender, obesity, tobacco smoking and duration of bronchial asthma, and the patients were tested for allergy to house dust mites, animal fur, mold spores, cockroach allergens and hypersensitivity to non-steroid anti-inflammatory drugs (NSAIDs); any such allergies could play a role in glucocorticoid resistance and the data could provide an insight into whether they were primary or secondary to genetic factors. Detailed information was also obtained from the medical records of particular patients.

If no spirometry or allergology data were available, such examinations were additionally performed during the recruitment visit. The spirometry tests were conducted in the Outpatient Department according to the ERS (European Respiratory Society) / ATS (American Thoracic Society) standards, whereas the allergology tests were performed according to the EAACI (European Academy of Allergy and Clinical Immunology) guidelines $[20,21,22,23,24,25]$.

The following participants were excluded from the study: those suffering from clinically-significant exacerbations, those using drugs which might have induced resistance to glucocorticoids (such as rifampicin, phenobarbital, phenytoin, ephedrine), subjects with signs of viral infections, either generalized, or affecting the respiratory tract, as well as subjects failing to comply with the doctor's recommendations

Nasal allergen challenge

The nasal allergen challenge (NAC) was performed in accordance with current EAACl standards and in compliance with the manufacturer's recommendations (Allergopharma challenge test solutions, Manufacturer: Allergopharma GmbH \& Co. KG Hermann-Koerner-Str. 52 D-21465, Reinbek, Germany; Marketing Authorisation Number: 9531). The intranasal provocation test was performed with the use of the spray method, i.e. by administering standardized test solutions of $0.04-0.05 \mathrm{ml}$ through a spray nozzle supplied and approved for use by the manufacturer. The following test solutions were prepared: 1st provocation: dilution 1:10000 (or more in highly-sensitive patients), 2nd provocation: dilution 1:1000, 3rd provocation: dilution 1:100, 4th provocation: dilution 1:10 and 5th provocation: undiluted test solution. The spray nasal allergen challenge was performed according to the approved for distribution/use protocol No. 9531, available on the manufacturer's website $[26,27,28]$.

Methacholine challenge test

Methacholine provocation was performed according to the ERS technical standard on bronchial challenge testing: general considerations and performance of methacholine challenge tests. The patient first underwent basic spirometry to obtain a baseline FEV1 score. Following this, the patient inhaled a gradually increasing amount of methacholine to cause bronchospasm using a dispenser. FEV1 change from baseline was assessed. A reduction in FEV1 of $\geq 20 \%$ was considered significant and the provocative concentration (PC20) or provocative dose (PD20) was determined for this value [29].

Expression of mRNA by qRT-PCR 
Venous blood samples were collected from the participants onto tripotassium ethylenediaminetetraacetic acid (EDTA-K3; SARSTEDT AG \& Co.; Nümbrecht, Germany).

Briefly, $10 \mu \mathrm{g}$ Total RNA was extracted from the peripheral blood leukocytes using RNA extraction reagent, (TRI Reagent ${ }^{\circledR}$ Solution, Ambion, NY, USA), according to the standard acid-guanidinium-phenol-chlorophorm method [32]. The extracted RNA was analyzed with agarose gel electrophoresis and only cases with preserved $28 \mathrm{~S}, 18 \mathrm{~S}$ and 5 S ribosomal RNA bands, indicating good RNA quality, were used in the study. The amount of purified RNA was determined using spectrophotometry at $260 \mathrm{~nm}$ in a Nanodrop analyser (ND-100; Nanodrop Technologies, Wilmington, Germany, US). The purity and amount was verified according to the absorbance ratio at $260 / 280 \mathrm{~nm}$ : values between 1.8 and 2.1 indicated that the optimal quality and that the mRNA was suitable for qRT-PCR analysis [12,21,32]. The analysis of the studied genes was performed in the Laboratory of Personalized Medicine and Biotechnology Laboratory of BioNanoPark, Regional Science and Technology Park in Lodz (93-465 Lodz, Poland).

The following genes were analysed:

- mitogen-activated kinases MAPK 1 and MAPK3, which play a role in regulating the response to external signals reaching the cell and influence gene expression, division, differentiation, movement and apoptosis of cells,

- SMAD family genes SMAD1, SMAD3, SMAD6 and SMAD7, encoding proteins serving as signal transducers and transcription modulators and which mediate many signaling pathways,

- transforming growth factors TGF- $\beta 1$ (transforming growth factor $\beta 1$ - controls cell growth, proliferation, differentiation and apoptosis) and TGF- $\beta 3$ (transforming growth factor $\beta 3$ ).

The $\beta-2$ microglobulin ( $\beta-2 \mathrm{M})$ gene was used as an internal control, which demonstrates constant expression in the tested samples. Appropriate TaqMan probes were selected for the eight test genes and the housekeeping gene $(\beta-2 M)$ (Table 1). TaqMan probes are hybridization probes designed to increase the specificity of Real-Time PCR reactions.

Table 1. Analyzed genes and the applied TaqMan probes.

\begin{tabular}{ll} 
Gene & Assay ID \\
\hline SMAD1 & Hs00195432_m1 \\
\hline SMAD3 & Hs00969210_m1 \\
\hline SMAD6 & Hs00178579_m1 \\
\hline SMAD7 & Hs00998193_m1 \\
\hline TGF- 11 & Hs00998133_m1 \\
\hline TGF- $\beta 3$ & Hs01086000_m1 \\
\hline MAPK1 & Hs01046830_m1 \\
\hline MAPK3 & Hs00385075_m1 \\
\hline$\beta-2 M$ & Hs00187842_m1
\end{tabular}


For each sample, CT (threshold cycle) values were calculated with the use of Mx-Pro software. The qRT-PCR amplification of each gene was determined by $\triangle \mathrm{CT}$ calculation $(\triangle \mathrm{CT}=\mathrm{CT}$, GENE $-\mathrm{CT}, \beta-2 \mathrm{M})$ relative to the housekeeping gene $(\beta-2 M)$. The qRT-PCR data was automatically calculated with the data analysis module. The results were analyzed according to the $2^{\wedge}(-\triangle \Delta C T)$ method with assumption of $100 \%$ reaction yield. Validation of PCR efficiency was performed with a standard curve $[12,13,21,30,31,32]$. The cDNA was subjected to real-time qPCR using gene-specific primers for the studied genes and $\beta-2 M$ with the use of the TaqMan Sonds $®$ \& Master Mixes for qRT-PCR (Biotium, Inc., CA, US).

A preliminary optimization stage was performed for the reaction conditions, following this, the expression of the studied genes was determined in all samples. A detailed description of the conditions of the qRT-PCR reaction is presented in Table 2.

Table 2. qRT-PCR reaction conditions for the analyzed expression of the studied genes.

\begin{tabular}{llll} 
Stage & Temperature $[\llbracket \mathrm{C}]$ & Time $[\mathrm{s}]$ & Number of cycles \\
\hline UNG incubation & 50 & 120 & 1 \\
\hline Polymerase activation & 95 & 600 & 1 \\
\hline Denaturation & 95 & 15 & 45 \\
\hline Annealing & 60 & 60 & 45
\end{tabular}

Assays were performed in two repetitions for each sample using a Real-Time PCR Optical Thermocycler (Biometra Biomedizinische Analytik $\mathrm{GmbH}$, Germany). The results were taken as averaged $\mathrm{Ct}$ (threshold cycle) values for the two replicates. Ct is the number of amplification cycles of the PCR product in which the fluorescence level of the dye exceeds the threshold, called the limit cycle. Based on the Ct value, it is possible to determine the amount of baseline cDNA for the selected genes in the studied sample, and thereby determine their expression $[12,13,21,30,31,32,33]$.

Data analysis

Analysis of missing data was included in the investigation. Blood sampling in at least two out of three time points was sufficient for a patient to be included in the study.

Missing Ct values in qPCR were imputed based on the conditional expectation calculated in the expectationmaximization algorithm [34]. Missing $\Delta$ Ct values for dropouts were imputed with the multiple imputation by chained equations (MICE) under a missing at random assumption about the unobserved data. The main analysis was performed in a fully-imputed dataset. Moreover, two sensitivity analyses were carried out: 1) dataset before the MICE procedure, 2) fully imputed dataset with adjustment for potential confounders (asthma diagnosis, perennial allergy, administration of inhaled corticoids in a dose exceeding $1000 \mu \mathrm{g}$ budesonide a day, administration of systemic steroids within the past three months, current cigarette smoking).

One-way repeated measures analysis of variance (ANOVA) was performed in order to assess whether the gene expression changed over time following both the provocations. To evaluate this effect, the minimum size of the patient sample was estimated to be 43 , with an assumption of Cohen's $f$ of 0.25 (default medium effect size), correlation between repeated measures of 0.5 , with power set to 0.95 and correction for non-sphericity being not 
included. Two-way repeated measures ANOVA with two-way interaction was performed to determine whether the provocation type affected the gene expression over time. In the case of sensitivity analysis 1 (with missing data), a mixed effects model was fitted instead of ANOVA. Sensitivity analysis 2 was performed with general linear modeling. The Greenhouse-Geisser correction was applied to adjust to potential lack of sphericity in each of the analyses.

Explorative factor analysis was used for dimensionality reduction, with varimax raw rotation to further explore the interrelation of gene expression. The analysis was performed following the Kaiser-Meyer-Olkin measure calculation and Bartlett's test of sphericity, according to the eigenvalue-below-one and scree plot criterion.

$P$-values below 0.05 were considered statistically significant. The analysis was performed using STATISTICA 13.1 software (StatSoft, Tulsa, OK, US) and the MICE procedure was carried out on R Software version 3.6.1 (R Core Team 2019).

\section{Results}

A total of 120 asthmatic patients were invited to participate in the study. The inclusion and exclusion criteria were met by 98 patients. From this patient group, another nine subjects could not be administered an allergen challenge with intranasal provocation because they did not comply with the grace period for antihistamines, and another 13 subjects could not be administered a methacholine challenge because they failed to comply with the grace period for inhaled drugs. One participant dropped out for family reasons. Therefore, 75 people were included to the study.

Four (5\%) patients were missing at time-point “0 h", eight (11\%) in time-point “+1 h" and 56 (75\%) at time-point "+24 h".

The number of no-detects in qRT-PCR depended on the gene, and ranged from three (1.9\% for TGF $\beta 1)$ to 128 (81.5\% for SMAD6), with a median value of 29.5 (18.8\%).

Of the 75 subjects included in the study, 27 (36\%) were applied an intranasal provocation, viz. 9 men and 18 women, and 48 (64\%) received a methacholine provocation: 17 men and 31 women. The two subgroups did not differ by gender proportion. Detailed characteristics of both study populations, including demographic and clinical parameters, are presented in Table 3.

Table 3. Demographic and clinical characteristics of the study participants divided into two subgroups: nasal allergen challenge (NAC) and methacholine test (MET). Footnotes to tables: 1 - if not stated otherwise; 2 Pearson's $\chi^{2}$ test; 3 - Student's $t$-test; 4 - Mann Whitney $U$ test; 5 - Fisher's exact test; 6 - pack-year - number of packs of cigarettes smoked daily, $x$ number of years of smoking; 7 - other pulmonary diseases including: sarcoidosis, ectasis, tuberculosis (TBC), chronic obstructive pulmonary disease (COPD). A detailed description in the article. The author's own design. 


\begin{tabular}{|c|c|c|c|c|}
\hline \multirow[t]{2}{*}{ Variable } & \multicolumn{3}{|c|}{ Number (frequency) or mean (standard deviation) ${ }^{1}$} & \multirow{2}{*}{$\begin{array}{l}p \text {-value for } \\
\text { comparison }\end{array}$} \\
\hline & Total $(n=75)$ & MET $(n=48)$ & NAC $(n=27)$ & \\
\hline \multicolumn{5}{|l|}{ Sex } \\
\hline Male & $26(35 \%)$ & $17(35 \%)$ & $9(33 \%)$ & \multirow[t]{2}{*}{$0.86^{2}$} \\
\hline Female & $49(65 \%)$ & $31(65 \%)$ & $18(67 \%)$ & \\
\hline \multicolumn{5}{|l|}{ Age } \\
\hline [years] & $39.7(15.6)$ & $43.5(16.2)$ & $32.8(11.7)$ & $0.0036^{3}$ \\
\hline \multicolumn{5}{|l|}{ BMI } \\
\hline$\left[\mathrm{kg} / \mathrm{m}^{2}\right]$ & $25.4(4.9)$ & $25.9(4.9)$ & $24.6(5.0)$ & $0.27^{3}$ \\
\hline \multicolumn{5}{|l|}{ Allergy } \\
\hline Seasonal & $28(37 \%)$ & $10(21 \%)$ & $18(67 \%)$ & $<0.0001^{2}$ \\
\hline Perennial & $\begin{array}{l}25(34 \%) \\
(n=74)\end{array}$ & $\begin{array}{l}12(26 \%) \\
(n=47)\end{array}$ & $13(48 \%)$ & $0.048^{2}$ \\
\hline Number of allergens: & $\begin{array}{l}2.0(2.6) \\
\text { median }\left(1^{\text {st }}-3^{\text {rd }}\right. \\
\text { quartile }): 0(0- \\
4) \\
\text { range: } 0-9 \\
(n=74)\end{array}$ & $\begin{array}{l}1.4(2.6) \\
\text { median }\left(1^{\text {st }}-3^{\text {rd }}\right. \\
\text { quartile }): 0(0- \\
2) \\
\text { range: } 0-9 \\
(n=47)\end{array}$ & $\begin{array}{l}3.0(2.3) \\
\text { median }\left(1^{\text {st }}-3^{\text {rd }}\right. \\
\text { quartile }): 3(0- \\
5) \\
\text { range: } 0-7\end{array}$ & $0.0017^{4}$ \\
\hline \multicolumn{5}{|l|}{ Nicotine smoking } \\
\hline Current smokers & $13(17 \%)$ & $11(23 \%)$ & $2(7 \%)$ & $0.12^{5}$ \\
\hline $\begin{array}{l}\text { Has not smoked for at least } 6 \\
\text { months; used to smoke }\end{array}$ & $18(24 \%)$ & $13(27 \%)$ & $5(19 \%)$ & $0.40^{2}$ \\
\hline Number of pack-years ${ }^{6}$ & $\begin{array}{l}4.3(8.5) \\
\text { median }\left(1^{\text {st }}-3^{\text {rd }}\right. \\
\text { quartile) }: 0(0- \\
5) \\
\text { range: } 0-42\end{array}$ & $\begin{array}{l}5.1(9.5) \\
\text { median }\left(1^{\text {st }}-3^{\text {rd }}\right. \\
\text { quartile }): 0(0- \\
6) \\
\text { range: } 0-42\end{array}$ & $\begin{array}{l}3.0(6.5) \\
\text { median }\left(1^{\text {st }}-3^{\text {rd }}\right. \\
\text { quartile }): 0(0- \\
1) \\
\text { range: } 0-20\end{array}$ & $0.13^{4}$ \\
\hline \multicolumn{5}{|l|}{ Rhinitis } \\
\hline $\begin{array}{l}\text { Rhinitis } \\
\text { (any type) }\end{array}$ & $53(71 \%)$ & $28(58 \%)$ & $25(93 \%)$ & $0.0018^{2}$ \\
\hline Rhinitis treated with nasal GCSs & $19(25 \%)$ & $6(13 \%)$ & $13(48 \%)$ & $0.0007^{2}$ \\
\hline Episodic rhinitis & $17(23 \%)$ & $12(25 \%)$ & $5(19 \%)$ & $0.52^{2}$ \\
\hline
\end{tabular}




\begin{tabular}{|c|c|c|c|c|}
\hline Chronic rhinitis & $38(51 \%)$ & $16(33 \%)$ & $22(81 \%)$ & $<0.0001^{2}$ \\
\hline Seasonal rhinitis & $19(25 \%)$ & $12(25 \%)$ & $7(26 \%)$ & $0.93^{2}$ \\
\hline Perennial rhinitis & $36(48 \%)$ & $16(33 \%)$ & $20(74 \%)$ & $0.0007^{2}$ \\
\hline \multicolumn{5}{|l|}{ Medication use } \\
\hline anti- $\mathrm{H}_{1}$ & $30(40 \%)$ & $16(33 \%)$ & $14(52 \%)$ & $0.12^{2}$ \\
\hline PPI & $8(11 \%)$ & $6(13 \%)$ & $2(7 \%)$ & $0.70^{5}$ \\
\hline anti - $\mathrm{H}_{2}$ & $2(3 \%)$ & $1(2 \%)$ & $1(4 \%)$ & $1.00^{5}$ \\
\hline Intolerance, hypersensitivity to drugs & $4(5 \%)$ & $3(6 \%)$ & $1(4 \%)$ & $1.00^{5}$ \\
\hline \multicolumn{5}{|l|}{ Comorbidities } \\
\hline $\begin{array}{l}\text { Nasal polyps current, recurrent, } \\
\text { postoperative }\end{array}$ & $3(4 \%)$ & $2(4 \%)$ & $1(4 \%)$ & $1.00^{5}$ \\
\hline $\begin{array}{l}\text { Neurological or neurosurgical } \\
\text { diseases }\end{array}$ & $19(25 \%)$ & $15(31 \%)$ & $4(15 \%)$ & $0.12^{2}$ \\
\hline $\begin{array}{l}\text { Lipid disturbances, } \\
\text { including } \\
\text { hypercholesterolemia }\end{array}$ & $5(7 \%)$ & $5(10 \%)$ & $0(0 \%)$ & $0.15^{5}$ \\
\hline Goiter & $1(1 \%)$ & $1(2 \%)$ & $0(0 \%)$ & $1.00^{5}$ \\
\hline Hypoactivity & $2(3 \%)$ & $2(4 \%)$ & $0(0 \%)$ & $0.53^{5}$ \\
\hline Hyperactivity & $4(5 \%)$ & $4(8 \%)$ & $0(0 \%)$ & $0.29^{5}$ \\
\hline Atherosclerosis & $1(1 \%)$ & $1(2 \%)$ & $0(0 \%)$ & $1.00^{5}$ \\
\hline Hypertension & $10(13 \%)$ & $8(17 \%)$ & $2(7 \%)$ & $0.31^{5}$ \\
\hline Arrhythmia & $5(7 \%)$ & $5(10 \%)$ & $0(0 \%)$ & $0.15^{5}$ \\
\hline Myocardial infarction & $1(1 \%)$ & $1(2 \%)$ & $0(0 \%)$ & $1.00^{5}$ \\
\hline Other cardiac diseases & $2(3 \%)$ & $2(4 \%)$ & $0(0 \%)$ & $0.53^{5}$ \\
\hline Other pulmonary diseases ${ }^{7}$ & $1(1 \%)$ & $1(2 \%)$ & $0(0 \%)$ & $1.00^{5}$ \\
\hline Gastric ulcer & $4(5 \%)$ & $3(6 \%)$ & $1(4 \%)$ & $1.00^{5}$ \\
\hline Duodenal ulcer & $1(1 \%)$ & $1(2 \%)$ & $0(0 \%)$ & $1.00^{5}$ \\
\hline $\begin{array}{l}\text { Reflux diseases or suspicion of } \\
\text { reflux disease }\end{array}$ & $10(13 \%)$ & $8(17 \%)$ & $2(7 \%)$ & $0.31^{5}$ \\
\hline $\begin{array}{l}\text { Neoplasmatic diseases or medical } \\
\text { history of neoplasmatic disease }\end{array}$ & $1(1 \%)$ & $1(2 \%)$ & $0(0 \%)$ & $1.00^{5}$ \\
\hline Immunodeficiency disorders & $3(4 \%)$ & $2(4 \%)$ & $1(4 \%)$ & $1.00^{5}$ \\
\hline
\end{tabular}


The results indicate that both the intranasal allergen challenge (specific agents) and methacholine challenge (non-specific agent) influenced the relative expression of genes of the TGF- $\beta$ (TGF- $\beta 1$ and TGF- $\beta 3$ ) - Smad (MPK1/3, Smad1/3/6/7) signaling pathway in the peripheral blood leukocytes. Relative changes in expression were found for the TGF- $\beta 1$, MAPK1, MAPK3, Smad3, Smad6 and Smad7 genes. No significant changes over time were observed for TGF- $\beta 3$ and Smad1 genes following the provocations. Detailed results are presented in Table 4.

Table 4. mRNA gene expression changes over time following provocation; relative gene expression was calculated as a ratio of gene expression at the $+24 \mathrm{~h}$ time-point vs. $0 \mathrm{~h}$ time-point. The analysis was performed for total sample of allergen and methacholine provocation patients.

\begin{tabular}{|c|c|c|c|c|c|c|c|c|c|}
\hline & & MAPK1 & MAPK3 & SMAD1 & SMAD3 & SMAD6 & SMAD7 & TGF- $\beta 1$ & $\begin{array}{l}\text { TGF- } \\
\text { ß3 }\end{array}$ \\
\hline \multirow[t]{2}{*}{$\begin{array}{l}\text { Effect } \\
\text { size }\end{array}$} & $\begin{array}{l}\text { Relative } \\
\text { gene } \\
\text { expression } \\
(95 \% \mathrm{Cl})\end{array}$ & $\begin{array}{l}0.71 \\
(0.53- \\
0.96)\end{array}$ & $\begin{array}{l}0.60 \\
(0.45- \\
0.80)\end{array}$ & $\begin{array}{l}0.63 \\
(0.41- \\
0.98)\end{array}$ & $\begin{array}{l}0.58 \\
(0.42- \\
0.80)\end{array}$ & $\begin{array}{l}0.40 \\
(0.24- \\
0.66)\end{array}$ & $\begin{array}{l}0.39 \\
(0.21- \\
0.72)\end{array}$ & $\begin{array}{l}2.27 \\
(1.40- \\
3.69)\end{array}$ & $\begin{array}{l}0.84 \\
(0.47- \\
1.50)\end{array}$ \\
\hline & Partial $\eta^{2}$ & $4.65 \%$ & $8.58 \%$ & $3.47 \%$ & $8.16 \%$ & $8.36 \%$ & $7.72 \%$ & $10.21 \%$ & $0.69 \%$ \\
\hline \multicolumn{2}{|c|}{$\begin{array}{l}P \text {-value in } \\
\text { main analysis }\end{array}$} & 0.038 & 0.0014 & 0.078 & 0.0021 & 0.0017 & 0.0054 & 0.0007 & 0.58 \\
\hline \multicolumn{2}{|c|}{$\begin{array}{l}P \text {-value in } \\
\text { sensitivity analysis } \\
1\end{array}$} & 0.20 & 0.037 & 0.066 & 0.11 & 0.013 & 0.0026 & 0.18 & 0.097 \\
\hline \multicolumn{2}{|c|}{$\begin{array}{l}P \text {-value in } \\
\text { sensitivity analysis } \\
2\end{array}$} & 0.13 & 0.034 & 0.12 & 0.021 & 0.046 & 0.021 & 0.0026 & 0.091 \\
\hline
\end{tabular}

A data analysis was also performed in order to determine whether the provocation type affected gene expression over time. However, we did not analyze the influence of specific provocation on the change in gene expression (Table 5).

Table 5. Difference in mRNA gene expression changes over time following intranasal and methacholine provocations.

\begin{tabular}{|c|c|c|c|c|c|c|c|c|}
\hline Variable & MPK1 & MPK3 & SMAD1 & SMAD3 & SMAD6 & SMAD7 & TGFB1 & TGFB3 \\
\hline Partial $\eta^{2}$ & $0.28 \%$ & $1.41 \%$ & $0.90 \%$ & $2.01 \%$ & $1.69 \%$ & $2.36 \%$ & $4.14 \%$ & $0.63 \%$ \\
\hline$P$-value in main analysis & 0.77 & 0.35 & 0.50 & 0.23 & 0.29 & 0.18 & 0.053 & 0.61 \\
\hline $\begin{array}{l}P \text {-value in sensitivity } \\
\text { analysis } 1\end{array}$ & 0.70 & 0.67 & 0.49 & 0.85 & 0.66 & 0.15 & 0.88 & 0.40 \\
\hline $\begin{array}{l}P \text {-value in sensitivity } \\
\text { analysis } 2\end{array}$ & 0.64 & 0.070 & 0.33 & 0.11 & 0.18 & 0.35 & 0.20 & 0.90 \\
\hline
\end{tabular}

The changes in the expression of TGF- $\beta$ (TGF- $\beta 1$ and TGF- $\beta 3$ ) - Smad (MPK1/3, Smad1/3/6/7) signaling pathway genes are presented according to provocation type in Fig 1. Despite relatively small changes in 
expression, both the intranasal allergen or methacholine challenges demonstrated similar downward trends in the relative expression of Smad (MPK1/3, Smad1/3/6/7); however, an increase in TGF- $\beta 1$ was noted, as well as a non-significant effect on TGF- $\beta 3$. The observed relationships are visualized as mean $-\Delta \mathrm{Ct}$ values (Figure 1 ).

The similarity between gene expression over time between provocation types, based on the Kaiser-Meyer-Olkin measure and Bartlett's test of sphericity, prompted further study of the relationships between the analyzed genes. provided adequate rationale for this. Reducing the dimensionality of gene expression to two factors retained as much as almost $70 \%$ of variance, as shown in Figure 2; this indicates a high intercorrelation between the expression of the tested genes, particularly SMAD1/3/6, MAPK1/3 and TGF $\beta 3$, as well as a negative correlation between SMAD7 and TGF $\beta 1$.

\section{Discussion}

Our findings indicate that extrinsic factors have a significant influence on the mRNA expression of key genes of the TGF- $\beta$ (TGF- $\beta 1$ ) - Smad (MPK1/3, Smad3/6/7) signaling pathway in peripheral blood leukocytes of asthmatic patients. This is true for both specific factors such as allergens, and non-specific ones, such as methacholine.

The provocative factors used in the present study increased the expression of the cytokine TGF- $\beta 1$ alone, i.e. no effect was observed for TGF- $\beta 3$. This is important in asthmatic patients because isoform 1 is the strongest known inducer of bronchial remodeling in asthmatic patients. It strongly induces macrophage and fibroblast chemotaxis, and stimulates fibroblast proliferation and synthesis; it also stimulates the synthesis of fibronectin, proteoglycans, collagen type I and III, enhances eosinophil chemotaxis after allergen exposure, and causes phosphorylation of MAPK kinases resulting in increased bronchial myocyte proliferation $[5,11,12,14,20,21]$. It should be noted, however, that inconsistent results regarding the change in TGF-beta 1 expression between two provocation types have been noted in previous studies, and the effects of particular provocation types remain inconclusive. Unfortunately, due to the low numbers of patients in the present study, no such analysis was possible.

Interestingly, both types of provocation resulted in an increase in relative gene expression for MAPK kinase isoforms 1 and 3 over time. This is an important observation because TGF- $\beta 1$ inhibits collagenase and matrix metalloproteinase gene expression, as well as MHC type II antigen expression and surfactant synthesis by type II pneumocytes. This inhibition is realized through TGF $\beta R I / T G F \beta R I I$ receptor (ALK5) and MAPK1/3 kinases, independent of Smad signaling proteins. These changes in expression may significantly reduce the progress of bronchial remodeling $[5,11,12,14,20,21]$.

No significant change in Smad1 gene expression was found after the allergen (specific) or methacholine challenge (non-specific) test; however, the results were close to the borderline of statistical significance and should be considered inconclusive. Therefore, it is possible that the change in Smad1 protein expression may be dependent on the ongoing underlying inflammation factors in asthma, or it may not. If Smad1 expression is related to provocation, this can probably be explained in many ways. One possibility is that Smad1 receives its signal from a different type of ALK receptor to Smad3, 6 or 7. Indeed, the ALK1, 2, 3 and 6 receptors are the main signal transducers from TGF- $\beta 1$ to Smad1, and not ALK5. Our findings also indicate a high correlation between Smad1 and the other tested genes, suggesting it may have a different function in response to specific and nonspecific provocations than the other studied Smad proteins $[5,10,17,18,19]$; however, these relationships only have borderline significance and allow for speculative discussion only.

Page $11 / 18$ 
Interestingly Smad3 mRNA expression changed after both types of provocation. A significant change in the relative expression of the Smad3 gene is known to correlate with activation of the Smad2/3 complex. It also stimulates the intranuclear Smad2/3/4 protein systems and TF, activating the transcription of target genes, including those responsible for bronchial remodeling in asthma, particularly the genes associated with MMPs, PAI-1, CTGF, MCP-1, IL-6, TGF- $\beta$, TSP-1, TGFR-1/2, fibronectine, proteoglycans, as well as type I and III collagen $[5,35,36,37]$.

As such, the role of the Smad6 and Smad7 proteins merits further consideration. These belong to the group of inhibitory proteins (I-Smad) for the TGF- $\beta$ - Smad signaling pathway, responding to signals transmitted by the ALK1 and ALK5 receptors, and their role in asthma has not been fully understood $[5,10,18,38,39,40]$.

The relative changes in expression of the genes of the TGF- $\beta$ - Smad signaling pathway were also subjected to exploratory factor analysis (Figure 2). Interestingly, the factors demonstrated a great deal of interrelatedness, with two apparently determining the clustering of the expression of the studied genes. The first leading factor correlates with the majority of genes (Smad1, 3 and 6, MAPK1 and 3, and TGF- $\beta 3$ ). The other is independent of most of these genes; however, it relates to Smad7 and TGF- $\beta 1$. This relationship also can be observed when analyzing similar trend lines for the changes in studied gene expression (Figure 1).

Most importantly, the factor analysis shows a high correlation between the expressions of certain genes, but not between the changes in the expression of the genes. As such, it cannot be claimed that a decrease in one of the TGF- $\beta 3$, MPK $1 / 3$ and Smad1/3/6 genes after a provocation entails a decrease of the other genes. The best interpretation of the results of the factor analysis would be that if the expression of one of these genes is high at any time point (before or after provocation) in a particular patient, the other genes also demonstrate high expression. Thus, the genes appear to "coordinate" their expression with one another.

These interrelations can be explained by the fact that the tested gene products interact via signal transduction. This is likely the first such report of their relationship, and may contribute to a deeper understanding of the molecular pathophysiology of asthma. TGF- $\beta 1$ is an important factor responding to external irritants in asthma, leading to activation of the two most important receptor groups ALK1 and ALK5, which in turn are responsible for further activation of the entire Smad and MAPK pathways.

It should be noted that sensitivity analyses were used to support the robustness of the obtained results. The observations were described using statistical methods with all appropriate statistical corrections, as noted in the Materials and Methods section.

\section{Limitations:}

Observations were made on 75 participants who underwent an intranasal allergen and bronchial methacholine challenge for diagnostic clinical indications, and who varied in terms of age and the number of allergens (see Table 3). It is a realistic observational study; the patients were allocated to groups based on diagnostic and therapeutic indications, but not randomly. The tests were performed on blood and not tissues, as this was most suitable for the analysis. The blood samples were only collected at three time points: 0 hours, i.e. baseline, one hour after provocation and 24 hours after provocation.

The patients were not isolated from external environmental factors for a sufficiently long time before specific and non-specific tests were performed. The results could also have been influenced by a number of confusing factors, 
including inter alia the medications taken by the patients, disease duration, comorbidities, duration of the challenge itself, smoking, mutations and polymorphic forms tested by genes, the level of oxidative stress and free radicals. Therefore the aim of the study is to demonstrate general trends and relationships rather than describe the strictly isolated biochemical and molecular reactions.

Furthermore, the study does not consider the role of BMP proteins, which can modify the expression of Smad1/5 and Smad4 by interacting with ALK1,2,3,6 receptors and interfering with the mRNA expression of the studied genes.

Multicentre experiments on comparable in vitro, animal and in vivo models, including several blood collections in patients at different time intervals after activation of standardized doses of specific and non-specific irritants would be a valuable addition to our work.

\section{Conclusion}

Both types of studied challenge influenced the expression of most genes in the TGF- $\beta$ (TGF- $\beta 1$ and TGF- $\beta 3$ ) Smad (MPK1/3, Smad1/3/6/7) signaling pathway in asthmatic patients. A significant change in the mRNA expression of the TGF- $\beta 1$ - MPK1/3 and Smad3/6/7 genes was observed after intranasal allergen and bronchial methacholine challenge. TGF- $\beta 1$ expression increased after methacholine and allergen provocation; this is believed to be the main factor activating the entire signaling pathway in asthma, and hence is of clinical significance. The consequent activation of ALK1 and ALK5 receptors by TGF- $\beta 1$ is followed by stimulation of Smad-independent and MAPK (Smad-independent) proteins: a leading factor responsible for bronchial remodeling in asthma.

The nature of this change in mRNA I-Smad expression in asthma remains unclear and requires further scientific studies. The asthmatic patients demonstrated a cluster change in the expression of groups of TGF- $\beta$ - Smad signaling pathway genes after provocation (cluster 1: TGF- $\beta 1$ and Smad7, and cluster 2: TGF- $\beta 3, \mathrm{MPK} 1 / 3$, Smad1/3/6); therefore, future studies should consider clustering genetic elements into asthma phenotypes and conducting a deeper analysis of the similarity of interactions between different groups of proteins involved in the chronic inflammatory process. The observed changes in gene expression are probably an adaptive reaction to the stimulation of TGF- $\beta$ / Smad and MPK pathway signaling.

The TGF- $\beta$-Smad signaling pathway is hence an important element in the modeling of bronchial inflammation in asthma. The mRNA expression of the TGF- $\beta 1-$ MPK1/3 and Smad3/6/7 genes changes after intranasal allergen and bronchial methacholine challenge. These findings have potential implications for asthma treatment.

\section{Declarations}

\section{Funding}

The study has been financed from the Polpharm Scientific Foundation, grant no. 16/XIV/2015, Poland.

\section{Competing interests}

The authors declare that there is no conflict of interest regarding publication of this article. 
Acknowledgements

Not applicable

\section{Authors' information}

Not applicable

\section{References}

1. Pelaia G, Vatrella A, Busceti MT, Gallelli L, Calabrese C, Terracciano R, Maselli R. Cellular mechanisms underlying eosinophilic and neutrophilic airway inflammation in asthma. Mediators Inflamm. 2015:879783.

2. Annunziato F, Romagnani C, Romagnani S. The 3 major types of innate and adaptive cell-mediated effector immunity. J Allergy Clin Immunol. 2015;135(3):626-35.

3. de Groot J, ten Brinke A, Bel E. Management of the patient with eosinophilic asthma: a new era begins. ERJ Open Res 2015; 1: 00024-2016. - July 01, 2016.

4. Wenzel SE. Asthma: defining of the persistent adult phenotypes. Lancet 2006; 368: 804-813.

5. Koćwin M, Jonakowski M, Przemęcka M, Zioło J, Panek M, Kuna P. The role of the TGF-SMAD signaling pathway in the etiopathogenesis of severe asthma. Adv Respir Med. 2016;84(5):290-301.

6. Heldin C, Aristidis Moustakas A. Signaling Receptors for TGF- $\beta$ Family Members. Cold Spring Harb Perspect Biol. 2016;1;8(8).

7. Venge P. The eosinophil and airway remodelling in asthma. Clin Respir J 2010; 4(Suppl 1): 15-9.

8. Torrego A, Hew M, Oates T i wsp. Expression and activation of TGF-beta isoforms in acute allergen-induced remodelling in asthma. Thorax 2007; 62(4): 307-13.

9. Czarniakowska-Bołtuć M, Ziętkowski Z, Bodzenta-Łukaszyk A. Role of selected growth factors in asthma. Alergia Astma Immunologia 2012, 17 (4): 172-179.

10. Derynck R, Zhang YE. Smad-dependent and Smad-independent pathways in TGF-beta family signalling. Nature. 2003 Oct 9;425(6958): 577-84.doi:10.1038/nature02006.

11. Panek M, Pietras T, Fabijan A, Zioło J, Wieteska $Ł$, Małachowska B, Fendler W, Szemraj J, Kuna P. Identification and association of the single nucleotide polymorphisms, C-509T, C+466T and T+869C, of the TGF- $\beta 1$ gene in patients with asthma and their influence on the mRNA expression level of TGF- $\beta 1$. Int J Mol Med. 2014 Oct;34(4): 975-86.doi: 10.3892/ijmm.2014.1894.

12. Panek M, Pietras T, Szemraj J, Fabijan A, Kuna P. Identification and association of TGF $\beta-1$ expression in patients with asthma in a Polish population - Lodz metropolitan area study. Int J Biochem Mol Biol. 2013; 4:6774. 
13. Panek M, Pietras T, Fabijan A, Miłanowski M, Wieteska L, Górski P, Kuna P, Szemraj J. Effect of glucocorticoid receptor gene polymorphisms on asthma phenotypes. Exp Ther Med. 2013; 5:572-580.

14. Mokrosiński J, Krajewska WM. TGFß signalling accessory receptors. Postepy Biochem. 2008;54(3):264-73.

15. de Caestacker M (2004) The transforming growth factor- $\beta$ superfamily of receptors. Cytokine Growth Factor Rev 15: 1-11.

16. Massague J (1998) TGF- $\beta$ signal transduction. Annu Rev Biochem 67:753-791.

17. Miyazawa K, Shinozaki M, Hara T, Furuya T, Miyazono K (2002) Two major Smad pathways in TGF- $\beta$ superfamily signalling. Genes Cells 7:1191-1204.

18. Hata A, Chen YG. TGF-beta Signaling from Receptors to Smads. Cold Spring Harb Perspect Biol. 2016 Sep 1;8(9):a022061. doi: 10.1101/cshperspect.a022061.

19. Hu HH, Chen DQ, Wang YN, Feng YL, Cao G, Vaziri ND, Zhao YY. New insights into TGF-beta/Smad signaling in tissue fibrosis. Chem Biol Interact. 2018 Aug 25;292:76-83. doi: 10.1016/j.cbi.2018.07.008. Epub 2018 Jul 11.

20. Panek M, Jonakowski M, Zioło J, Wieteska Ł, Małachowska B, Pietras T, Szemraj J, Kuna P. A novel approach to understanding the role of polymorphic forms of the NR3C1 and TGF- $\beta 1$ genes in the modulation of the expression of IL-5 and IL-15 mRNA in asthmatic inflammation. Mol Med Rep. 2016 Jun;13(6):4879-87.

21. Panek M, Pietras T, Fabijan A, Zioło J, Wieteska $Ł$, Małachowska B, Fendler W, Szemraj J, Kuna P. The NR3C1 Glucocorticoid Receptor Gene Polymorphisms May Modulate the TGF-beta mRNA Expression in Asthma Patients. Inflammation. 2015 Aug;38(4):1479-92.

22. Panek M, Pietras T, Fabijan A, Miłanowski M, Wieteska L, Górski P, Kuna P, Szemraj J. Effect of glucocorticoid receptor gene polymorphisms on asthma phenotypes. Exp Ther Med. 2013 Feb;5(2):572-580.

23. Panek M, Pietras T, Fabijan A, Zioło J, Wieteska L, Małachowska B, Fendler W, Szemraj J, Kuna P. Identification and association of the single nucleotide polymorphisms, C-509T, C+466T and T+869C, of the TGF- $\beta 1$ gene in patients with asthma and their influence on the mRNA expression level of TGF- $\beta 1$. Int J Mol Med. 2014 Oct;34(4):975-86.

24. Pietras T, Panek M, Tworek D, Oszajca K, Wujcik R, Górski P, Kuna P, Szemraj J. The Bcl I single nucleotide polymorphism of the human glucocorticoid receptor gene h-GR/NR3C1 promoter in patients with bronchial asthma: pilot study. Mol Biol Rep. 2011 Aug;38(6):3953-8.

25. Pietras T, Panek M, Kuprys-Lipinska I, Oszajca K, Wujcik R, Kuna P, Gorski P, Szemraj J. Frequencies of Bcl I, E22E, and N363S of h-GR/NR3C1 restriction fragment length polymorphisms of glucocorticoid receptor gene in Polish adult population. Med Sci Monit. 2010 Oct;16(10):CR475-9.

26. Akerlund A, Andersson M, Leflein J, Lildholdt T, Mygind N. Clinical trial design, nasal allergen challenge models, and considerations of relevance to pediatrics, nasal polyposis, and different classes of medication. $J$ Allergy Clin Immunol. 2005;115: S460-82. 
27. Ellis, A.K., Soliman, M., Steacy, L. et al. The Allergic Rhinitis - Clinical Investigator Collaborative (AR-CIC): nasal allergen challenge protocol optimization for studying AR pathophysiology and evaluating novel therapies. All Asth Clin Immun 11, 16 (2015). https://doi.org/10.1186/s13223-015-0082-0.

28. Augé J, Vent J, Agache I, Airaksinen L, Campo Mozo P, Chaker A, Cingi C, Durham S, Fokkens W, Gevaert P, Giotakis A, Hellings P, Herknerova M, Hox V, Klimek L, La Melia C, Mullol J, Muluk NB, Muraro A, Naito K, Pfaar O, Riechelmann H, Rondon C, Rudenko M, Samolinski B, Tasca I, Tomazic P, Vogt K, Wagenmann M, Yeryomenko G, Zhang L, Mösges R. EAACI Position paper on the standardization of nasal allergen challenges. Allergy. 2018 Aug;73(8):1597-1608. doi: 10.1111/all.13416.

29. Coates AL, Wanger J, Cockcroft DW, Culver BH; Bronchoprovocation Testing Task Force: Kai-Håkon Carlsen, Diamant Z, Gauvreau G, Hall GL, Hallstrand TS, Horvath I, de Jongh FHC, Joos G, Kaminsky DA, Laube BL, Leuppi JD, Sterk PJ. ERS technical standard on bronchial challenge testing: general considerations and performance of methacholine challenge tests. Eur Respir J. 2017 May 1;49(5):1601526. doi: 10.1183/13993003.01526-2016.

30. Panek M, Pietras T, Antczak A, Górski P, Kuna P, Szemraj J (2012): The role of functional single nucleotide polymorphisms of the human glucocorticoid receptor gene NR3C1 in Polish patients with bronchial asthma. Mol Biol Rep 39: 4749-4757.

31. Panek M, Pietras T, Szemraj J, Kuna P (2014): Association analysis of the glucocorticoid receptor gene (NR3C1) haplotypes (ER22/23EK, N363S, Bcll) with mood and anxiety disorders in patients with asthma. Exp Ther Med 8: 662-670.

32. Chomczynski, P., Sacchi, N. 1987. Single - step method of RNA isolation by acid guanidinium thiocyanatephenol - chloroform extraction. Analytical Biochemistry, 162:156-9.

33. Karbownik MS, Szemraj J, Wieteska $Ł$, Antczak A, Górski P, Kowalczyk E, Pietras T. Antipsychotic Drugs Differentially Affect mRNA Expression of Genes Encoding the Neuregulin 1-Downstream ErbB4-PI3K Pathway. Pharmacology. 2016;98(1-2):4-12. doi: 10.1159/000444534

34. McCall M, McMurray H, Land Hand, Almudevar A. On non-detects in qPCR data. Bioinformatics. 2014 Aug 15; 30(16): 2310-2316.

35. Christianson C, Goplen N, Zafar I, Irvin C, Good J Jr, Rollins D, Gorentla B, Liu W, Gorska M, Chu H, Martin R, Alam R. Persistence of asthma requires multiple feedback circuits involving type 2 innate lymphoid cells and IL33. J Allergy Clin Immunol. 2015;136(1):59-68.

36. Bartemes K, lijima K, Kobayashi T, Kephart G, McKenzie A, Kita H. IL-33-responsive lineage-CD25+CD44hi lymphoid cells mediate innate type 2 immunity and allergic inflammation in the lungs J. Immunol. 2012;188(3):1503-1513.

37. Lee Y, Yap H, Shaari K, Tham C, Sulaiman M, Israf D. Blockade of Eosinophil-Induced Bronchial EpithelialMesenchymal Transition with a Geranyl Acetophenone in a Coculture Model. Front Pharmacol. 2017;16; 8:837.

38. Asadi A, Yaghobi Nezhad D, Rafie Javazm A, Khanicheragh P, Mashouri L, Shakeri F, Abbasi M, Afrazian MS, Niknam Z, Abazari O. In Vitro Effects of Curcumin on Transforming Growth Factor- $\beta$-mediated Non-Smad 
Signaling Pathway, Oxidative Stress, and Pro-inflammatory Cytokines Production with Human Vascular Smooth Muscle Cells. Iran J Allergy Asthma Immunol. 2020 Feb 1;19(1):84-93. doi: 10.18502/ijaai.v19i1.2421.

39. Groneberg DA, Witt H, Adcock IM, Hansen G, Springer J. Smads as intracellular mediators of airway inflammation. Exp Lung Res. 2004 Apr-May;30(3):223-50. doi: 10.1080/01902140490276320.

40. Witkowska M, Smolewski P. Białka z rodziny SMAD: współczesna wiedza na temat ich ekspresji i potencjalnej roli w chorobach nowotworowych. Postepy Hig Med Dosw 2014; 68: 301-309.

\section{Figures}
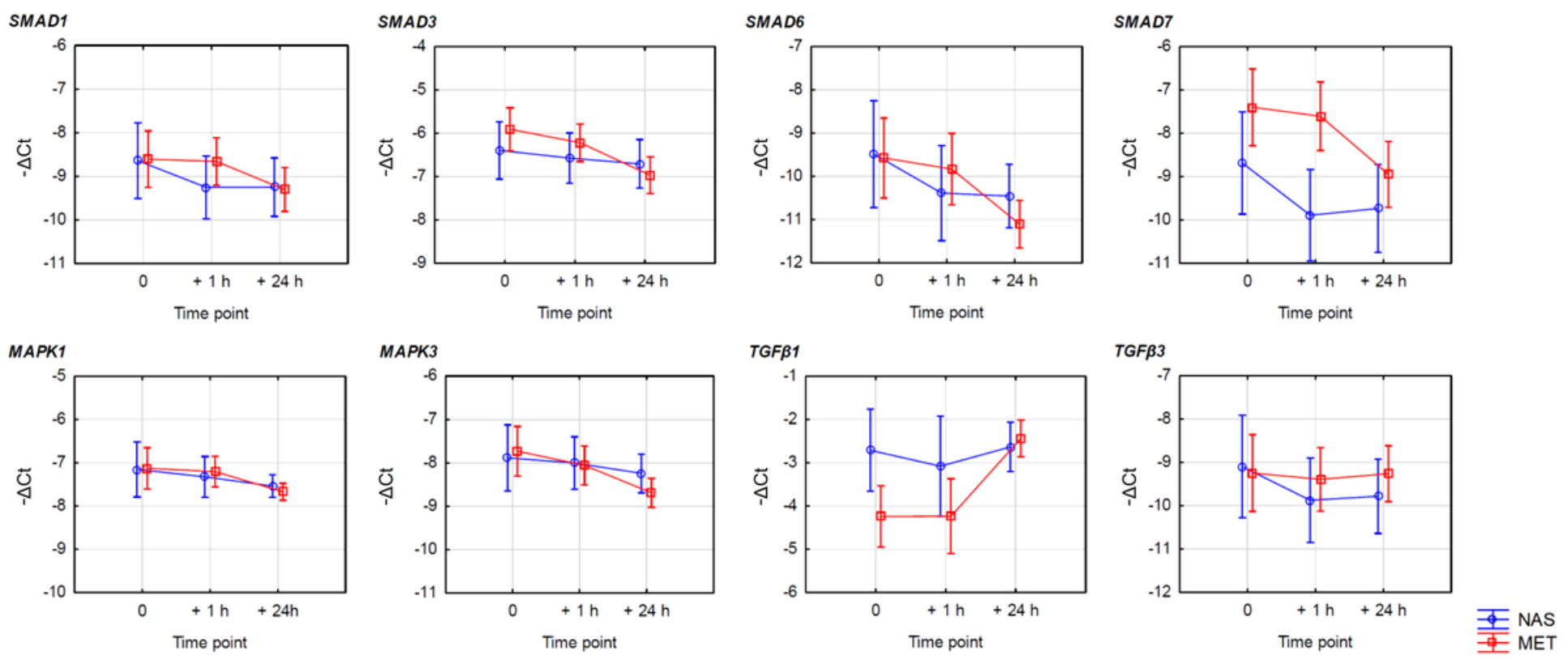

Figure 1

mRNA gene expression over time following provocation. Gene expression estimates are expressed as mean $-\Delta \mathrm{Ct}$ values (i.e. a decrease in the value by one unit indicates a two-fold decrease in gene expression) with the whiskers indicating 95\% confidence intervals. NAS - intranasal provocation, MET - methacholine provocation. 


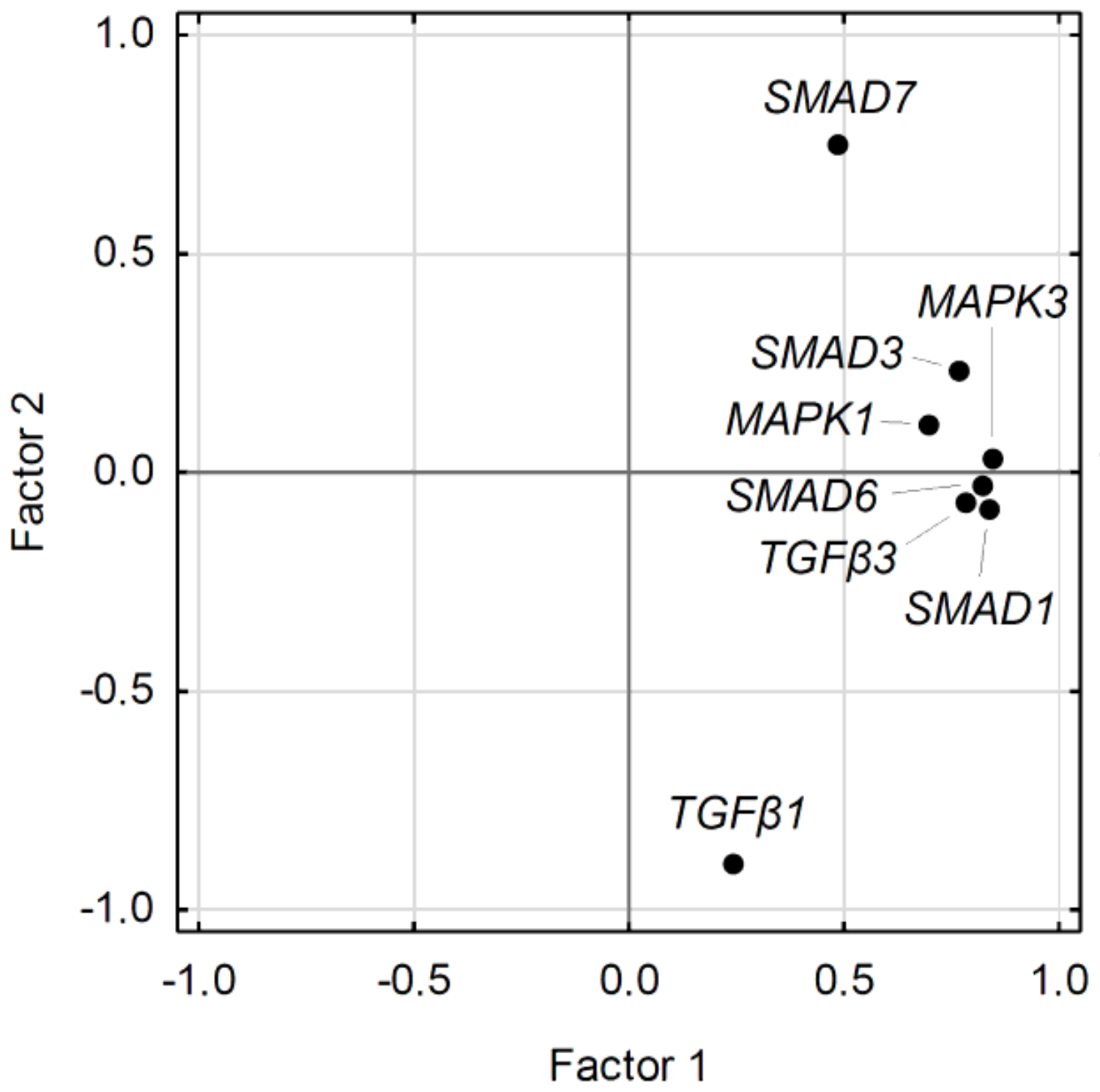

Figure 2

Relationships between the mRNA gene expressions in two-dimensional representation. Factor 1 retains $51.5 \%$ of variance, whereas Factor $2-17.6 \%$. Kaiser-Meyer-Olkin measure $=0.768$, the Bartlett's test of sphericity: $\neg \chi 2(28)$ $=960.0, p<0.0001$. The analysis was performed in a fully-imputed dataset. 